\title{
Environmental impact of greenhouse tomato production in France
}

\author{
Thierry Boulard • Caroline Raeppel • Richard Brun • \\ François Lecompte • Frank Hayer • G. Carmassi • \\ Gérard Gaillard
}

Accepted: 21 February 2011 / Published online: 24 June 2011

(C) INRA and Springer Science+Business Media B.V. 2011

\begin{abstract}
The environmental impact of greenhouse production in France is poorly documented. Environmental benefits versus drawbacks of greenhouse production are not well known. Assessments that intregrate pesticide toxicology and transfer of mass and energy are scarce. Here, we compared the main types of tomato production, heated, year-round production in plastic houses or glasshouses, and seasonal production under polytunnel. Environmental impacts where assessed by life cycle analysis. Analyses were performed after the construction of a database relating the integrality of matter and energy fluxes, regarding the structure of the system, the inputs for production, and the
\end{abstract}

T. Boulard $(\bowtie) \cdot R$. Brun

INRA, UR880 Unité de Recherches Intégrées en Horticulture, 400, route des Chappes, BP 167, 06903 Sophia-Antipolis, France e-mail: Thierry.Boulard@sophia.inra.fr

C. Raeppel

Physico-chimie de l'Atmosphère, Laboratoire des Matériaux, Surfaces et Procédés pour la Catalyse,

UMR 7515 CNRS-Université de Strasbourg,

1 rue Blessig,

67084 Strasbourg Cedex, France

F. Lecompte

INRA, UR 1115 Plantes et Systèmes de Cultures Horticoles, Domaine Saint Paul,

Site Agroparc,

84914 Avignon Cedex, France

F. Hayer $\cdot$ G. Gaillard

Agroscope Reckenholz-Tänikon Research Station ART,

8046 Zurich, Switzerland

G. Carmassi

DBPA, Dipartimento di Biologia delle Piante Agrarie,

University of Pisa,

Viale delle Piagge 23,

56124 Pisa, Italy waste products. Results show that greenhouse heating had the highest environmental impacts, including toxicological impact. For instance, the mean environmental impact of heated crops under plastic or in glasshouses was 4.5 times higher than in tunnels. Furthermore, pesticides in tunnels had a 3- to 6-fold higher impact in terms of terrestrial or aquatic ecotoxicology or human toxicology. Our results were compared with data from other temperate production regions.

Keywords Greenhouse tomato production - Environmental impact $\cdot$ Life cycle impact assessment

\section{Introduction}

\subsection{Greenhouse production: general features}

Having begun 50 years ago in northern Europe, the greenhouse cropping system is now a major production system supplying fresh fruit, vegetables, and ornamentals all year round throughout the world. In 2002, greenhouse production amounted to about $1,100,000$ ha, mostly fresh vegetables and ornamentals. The leader in greenhouse production is China, with 700,000 ha accounting for $90 \%$ of winter-spring vegetables north of latitude $32^{\circ}$ north (Tong et al. 2009). Developed countries are also dependent on protected vegetable production, e.g. South Korea (51\%) (Hong et al. 2008) and 40\% in France excluding potatoes (deduced from Jeannequin et al. 2005).

Land and water availability are strong determinants for agriculture, and extrapolating to the rest of the world the rough estimate that $50 \%$ of fresh vegetables are grown in protected conditions, we find that supplying half the world's fresh vegetable consumption requires less than 1 
million hectares under cover, i.e. a greenhouse area of only $100 \times 100 \mathrm{~km}$.

The water saving achieved by greenhouse production is impressive too and Challa and Bakker (1998) note that greenhouse production of $1 \mathrm{~kg}$ fresh tomatoes requires only a quarter of that needed in the open air. This is an exceptionally favourable factor for regions such as the Mediterranean where water resources are declining (Colino and Martínez 2002).

Plant health management is also favoured by protected cultivation and Nicot and Baille (1996) note that with enhanced environmental control in greenhouses, chemical pest management can be replaced by integrated pest management much more easily than in the open air.

However, most of the world's greenhouse areas are in regions with cold season where protected cropping extends the growing season to the entire year when using heating equipment and energy input. It is a major environmental concern as energy productivity (kilogrammes dry matter produced per MJ used) is 16 times less in a heated greenhouse than in an unheated one (Stanhill 1980).

\subsection{Environmental assessment of greenhouse production:} state of the art and needs

Greenhouse cropping is very specific because it uses techniques not used in other cropping systems: $\mathrm{CO}_{2}$ enrichment, artificial lighting, soilless cultivation and heating, which must be specifically addressed. The use of these techniques often has contradictory consequences for the environment: the impact per unit of cropping area is greater but the impact per unit of product is less. Both aspects need to be addressed and life cycle assessment (LCA) meets this requirement as it covers most impacts and considers the whole system. LCA is a tool for assessing the potential environmental impact of a production system (Heijungs et al. 1992) that considers the entire life cycle of the product from resource extraction to waste disposal. In one of the first LCA studies applied to agricultural systems, Jolliet (1993) established, for Swiss conditions, that " $\mathrm{CO}_{2}$ added to the air results in a higher yield per square metre and contributes to reduce energy consumption and pollution per kg tomatoes".

The environmental impact of soilless tomato growing was explored in Spain using LCA by Antón et al. (2004). They came to the conclusion that soilless cultivation with nutrient solution recycling techniques significantly reduces production impacts on the environment.

Quantification of the environmental impact of heating was studied in the Netherlands by Nienhuis (1996) and Pluimers et al. (2000). Both have shown that heating was the main cause of emissions of greenhouse gases, acidifying compounds and compounds causing eutrophication. For greenhouse tomato production in Great Britain, Williams et al. (2006) also found that heating was the main contributor to most impacts, but also that impact per kilogrammes of product depends very much on yield, the cost with organic and on-the-vine tomato production being often greater than for classic loose tomatoes, due to lower yields.

In Turkey, for warmer climatic conditions and simpler heating systems, Canakci and Akinci (2006) have estimated the contribution of heating to overall energy impact: $60 \%$ for tomato, $62 \%$ for pepper, and $54 \%$ for cucumber and eggplant; the tomato having the highest yield increase per unit energy input. They did not establish whether the increase in yield exceeded the increase in energy inputs but van Woerden (2001) tried to answer this important question for greenhouse systems representative of Dutch conditions. However, he did not compare the energy productivity (EP) of such systems with unheated production systems in the Netherlands or in warmer countries.

This review clearly shows that the environmental acceptability of greenhouse production strongly depends on its intensification. This is a controversial question and depending on the authors, the right equilibrium between the necessary limitation of the inputs and the required intensification of the system is never the same.

Based on these observations, we designed this study to quantify the environmental impact of greenhouse tomato production in France in the two main production regions (the lower Rhone valley and Catalogne for the south and lower Loire valley and Brittany for the north, representing $92 \%$ of fresh tomato production). This comparison allows us to examine whether there is a correlation between the environmental impact of tomato production and its geographical situation. Also we consider the dependence of the environmental impact of the production system on its degree of intensification. This is why we compared different levels of sophistication for heated greenhouses (plastic and glass houses) with simple cold walk-in tunnels which are also used for tomato production. However, as fresh (as opposed to processing) tomatoes are no longer grown in large quantities outdoors in France, field cropping has not been considered in this study.

\section{Materials and methods}

As the objective of this study was to compare the environmental impact of the French greenhouse tomato cultivation systems, we have considered the widespread ones: (1) soilless and heated tomato crops in glass or plastic multispans in the north-west (Brittany and lower Loire Valley) and in the south-east (Mediterranean area and the lower Rhone Valley) France and (2) in unheated, soil-based tomato production under high tunnels, also in south-east 
France. Details of areas and production per region are given in Table 1. Tunnels are mainly located in south-east and south-west (64.6\% and $17.0 \%$ of the total area, respectively) (Vésine et al. 2007; Agreste 2008a). The rest come from heated greenhouses, either glass (64\% of area) or inflated plastic houses $(6 \%)$ (Table 2).

\subsection{Main features of the system under investigation:} greenhouse tomato cropping systems in France

Bulk and truss tomatoes are produced in soilless and heated greenhouses whereas only bulk tomatoes are produced in cold and in soil tunnels. The average heated greenhouse area amounts to 2.35 ha per producer (Vésine et al. 2007), with planting from November to December in the southeast and December to January in the north-west, giving continuous harvesting between February and October (Table 2). A typical production system under tunnels is a succession of one or two lettuce or leafy vegetable crops in autumn and winter, followed by a row-crop such as tomato during spring and summer. Alternatively, the spring crop can be replaced by a green manure crop and/or soil solarization. Regardless of the type of greenhouse used, tomatoes are of several types which, for simplicity, we can group into three main types: classic loose, on the vine and "specialist" (cocktail, cherry, plum, and beef).

Energy and mineral inputs and waste, expressed per square metre of soil surface, are similar for all tomato types grown in heated greenhouses (Table 2). However, yields differ substantially according to the tomato type. The productivity of multi-span inflatable greenhouses is lower than for glasshouses in the north-west $(-20 \%)$ but similar in the south-east (Table 2). Yields in tunnels are much lower than in heated greenhouses; however, the cropping period is reduced by $50 \%$. Since yield is a crucial factor for the assessment of the environmental impact, we chose to consider the $\mathrm{kg}$ of tomatoes produced as the functional unit.

Two important production attributes, organoleptic quality and seasonality are partly integrated into the market price, as shown in Table 2. Within the same production period, cherry tomatoes are three times more expensive than truss tomatoes, the latter being $7.6 \%$ more expensive than loose tomatoes. During the tunnel production period, the average selling price is $20 \%$ lower than for the rest of the year.

\subsection{Data base elaboration}

The data on protected tomato cropping collected for this study are from 2006-2008. For all the studied production systems, we have considered the following subsystems: (1) structure (greenhouse structure and auxiliary equipment), (2) production, and (3) waste (including the management of the waste generated during and at the end of the crop cultivation). Production inputs were obtained from the management centres of the Chambers of Agriculture of the Brittany and Pays de Loire regions for the north-west and the Provence Côte d'Azur and Languedoc-Roussillon regions for the south-east. These data are quite representative as in France most of the tomato growers are members of these management centres, which record their members' practices in their statistics. For energy consumption, which needs a special focus, the data were taken from an in-depth investigation of energy consumption for greenhouse crops, conducted by two technical institutes (CTIFL, Astredhor) and the French Environment and Energy Management Agency (ADEME) during the years 2005 to 2007 (Vésine et al. 2007). Additional data were provided by various companies in the French horticultural sector (greenhouse construction, climate control, fertigation, etc.). Finally four

Table 1 Tomato production in France (from Agreste 2008b)

\begin{tabular}{|c|c|c|c|c|c|c|}
\hline & Brittany & Lower Loire valley & South-West & South-East & Other regions & France \\
\hline \multicolumn{7}{|l|}{ Surface (ha) } \\
\hline Heated greenhouses & 412 & 131 & 85 & 735 & 36 & 1,399 \\
\hline Glass & 387 & 127 & 72 & 654 & 36 & 1,276 \\
\hline Plastic & 25 & 4 & 13 & 81 & 0 & 123 \\
\hline Cold tunnels & 76 & 20 & 104 & 395 & 16 & 611 \\
\hline Total surface (ha) & 488 & 151 & 189 & 1,130 & 52 & 2,010 \\
\hline Total surface $(\%)$ & 24 & 7.5 & 9.5 & 56 & 3 & 100 \\
\hline \multicolumn{7}{|l|}{ Production (t) } \\
\hline Heated greenhouses & 165,807 & 43,069 & 29,369 & 222,372 & 6,298 & 466,915 \\
\hline Cold tunnels & 16,204 & 3,449 & 9,011 & 59,592 & 1,207 & 89,463 \\
\hline Total production $(\mathrm{t})$ & 182,011 & 46,518 & 38,380 & 281,964 & 7,505 & 556,378 \\
\hline Total production (\%) & 33 & 8 & 7 & 51 & 1 & 100 \\
\hline
\end{tabular}




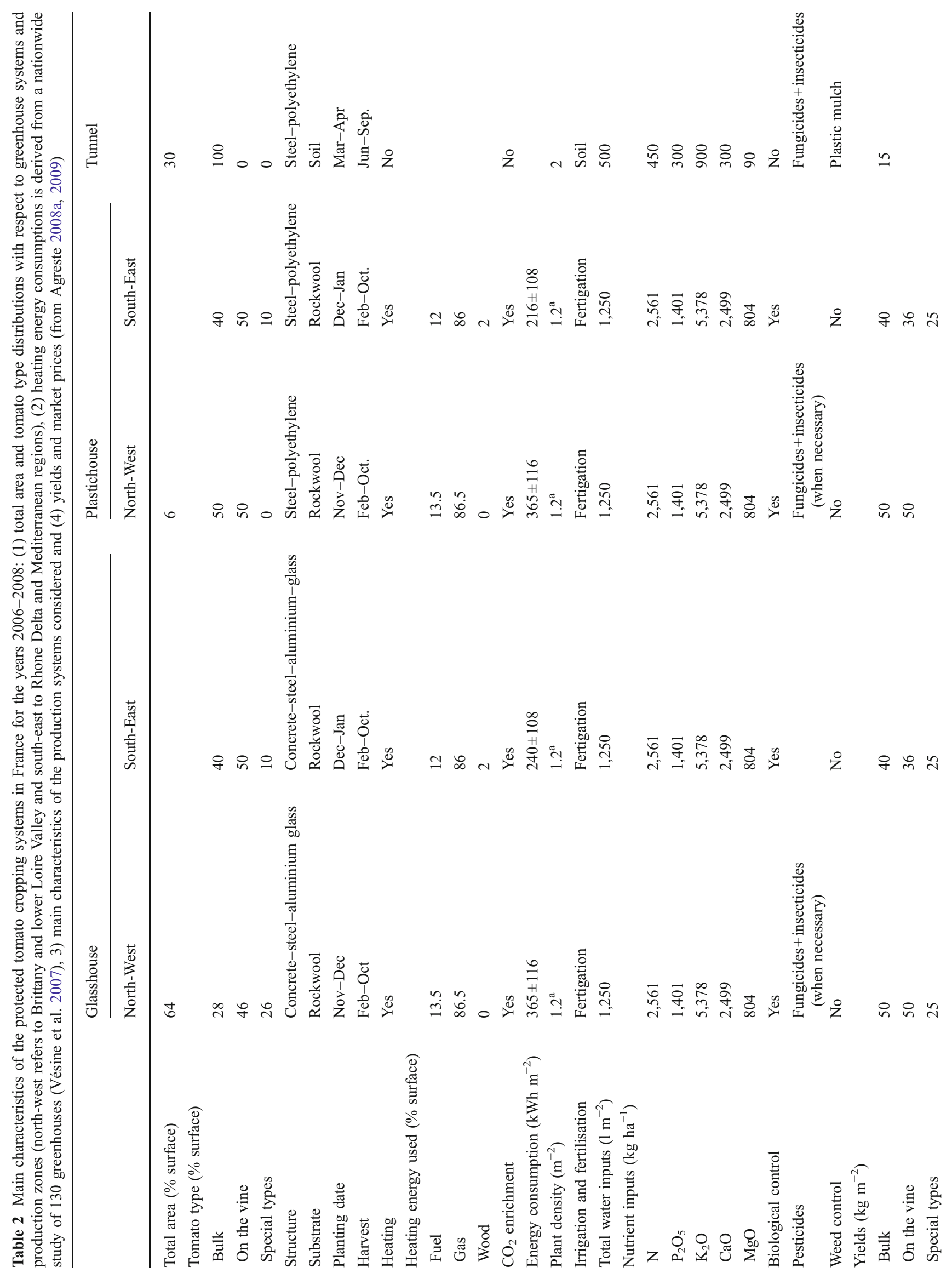


databases under the LCA software (SIMAPRO 2007) were also used to account for the various processes considered: (1) BUWAL 250 for the packaging, (2) IDEMAT 2001 for the production of the materials used, (3) LCA Food DK for the agricultural processes, and (4) ECOINVENT for energy extraction and processing.

\subsubsection{The greenhouse structures}

The costs of producing the structures of multi-span greenhouses and tunnels are included in this analysis. We considered in this study the structure of a Venlo type glasshouse manufactured in 2006 by the company CMF in Varades (France), while the structures of plastic greenhouses and tunnels where those manufactured in 2006 by the company Filclair in Venelles (France). Glasshouses are made of metal frames (steel and aluminium) with glass panes; their life span is 30 years. Concrete is used for the foundations and floors and various materials are used to construct boilers and packing sheds. Inflatable plastic greenhouses are composed of steel frames covered by a double polyethylene or ethyl-vinyl-acetate (EVA) film which is replaced approximately every 4 years. Tunnel frames are composed of steel arches, bars and wires and are covered with $0.35 \mathrm{~mm}$ grade polyethylene or EVA film which is also replaced every 4 years.

\subsubsection{Physical, chemical and biological inputs}

Glass and plastic multi-span greenhouses are equipped with heating systems consisting of steel boilers together with high and low temperature heating pipes. Various plastic pipes and pumps are used for irrigation, fertilisation, drainage and $\mathrm{CO}_{2}$ enrichment. Metal motors are used for vent opening control and electricity generation in case of electrical failure. Thermal and shade screens are normally used for energy savings and summer climate control. All these materials have a long life span and are written off over 10 to 30 years. Other components are replaced every 1-2 years; these include artificial substrates, various steel, or plastic crop support materials as well as twine (in polypropylene) and hooks. Tomato crops under glass and in plastic houses are grown on rock wool and coconut fibre substrates, respectively. These substrates generate 0.5 and $1 \mathrm{~kg}$ of waste per square metre, respectively. For rock wool, the recycling rate varies between $80 \%$ and $100 \%$. It is mixed with peat to made potting substrate $(80 \%)$ or used as inert material $(20 \%)$. Coconut fibre is recycled at $94 \%$ either to make compost $(56 \%)$ or substrate to be burnt for greenhouse heating (44\%). The manufacture of both substrates requires a lot of either energy (in the case of rock wool) or transport (coconut fibre). However, a recent study (Grasselly et al. 2009) has shown that the carbon 
footprint of the rock wool is three to six times higher than that of the coconut fibre.

Whitewash is also used every summer in the south-east. Plant health management is based on integrated pest management (IPM) but chemical pesticides (fungicides and insecticides) are used when biological control is ineffective or fails. Because of the shorter crop rotations in tunnels, biological control agents have more difficulty in settling and more pesticide is used; weeds are controlled with opaque polyethylene films laid on the ground and sometimes by herbicides.

\subsubsection{Energy and $\mathrm{CO}_{2}$ used}

Table 2 shows that average energy consumption is $52 \%$ higher in the north-west than in the south-east, with a very high standard deviation in both cases. It is about $10 \%$ less for inflatable plastic houses in the south-east. Heat energy sources other than gas (light and heavy oil and wood) account for less than $10 \%$ of total heated area. The heating systems (pumps and boilers) consume about $95 \%$ of the total electrical consumption of the farms. The energy produced is used for inside air heating to accelerate tomato growth and development but also for dehumidifying the greenhouse air (which adds about $20 \%$ to consumption). As the exhaust gas from combustion of natural gas is chemically stable, containing mainly $\mathrm{O}_{2}, \mathrm{CO}_{2}$, and $\mathrm{H}_{2} \mathrm{O}$, the $\mathrm{CO}_{2}$ produced can be fed into the greenhouse for $\mathrm{CO}_{2}$ enrichment to enhance photosynthesis. In France, about $70 \%$ of the heated greenhouse area uses such cogeneration systems for heat and $\mathrm{CO}_{2}$. A large quantity of $\mathrm{CO}_{2}$ is thus fixed as biomass during the growing season. However, this is temporary because it is emitted to the atmosphere following digestion by humans and disposal of residues and consequently we did not consider any avoidance of fossil $\mathbf{C}$ emissions. Apart from heat and $\mathrm{CO}_{2}$ cogeneration, there is also an increasing trend among the largest greenhouse tomato farms ( 7 ha on average) to combine heat and electricity generation as well as $\mathrm{CO}_{2}$. This applies in France to less than $20 \%$ of the heated area and this system will not be considered in our study. Unlike multispan greenhouses, tunnels are not heated at all and the tomato crop has no protection against frost, planting being simply delayed long enough in spring to avoid any risk of frost. Tunnels do not use $\mathrm{CO}_{2}$ enrichment or cogeneration.

\subsubsection{Fertilisation}

Soilless techniques are used in both glass and plastic multispan greenhouses. However, complete recycling of the nutrient solution, which eliminates leaching losses, is only practised on $20 \%$ of the soilless area. For the rest, $20 \%$ to $40 \%$ of excess water and nutrients are supplied and the leachate is spread on other arable crops or directly sent to drainage channels, with some pollution of the soil as well as surface water and groundwater.

For tunnel production, in addition to the green manure mentioned above, organo-mineral fertilisation is carried out at tillage and various tractors and machines are used for cultivation and chemical and organic fertiliser applications. Once the young tomatoes are planted, they are fertigated via polyethylene tubing.

\subsubsection{Waste emission}

Greenhouse waste management systems are quite diverse. According to information given by producers and professionals, a percentage of recycling is attributed to each element of the structure or coming from the crop. The waste scenario modelled took into account this percentage of recycling. The recycled materials were considered as avoiding costs and negative impacts. The fraction of the materials which was not recycled was associated with a specific form of disposal (e.g. inert material landfill) or disposed of in the general French waste system $(52 \%$ incineration and $48 \%$ landfill). Aluminium and steel from frames, agricultural machinery, boilers, heating pipes, and pumps was estimated to be recycled up to $70 \%$ to $90 \%$. Concrete and building waste were assumed to be sent to landfill sites for inert materials, but the impacts linked to this recycling way were not modelled. Between $20 \%$ and $30 \%$ of used plastic films (ADEME/FNCUMA, 2004) were assumed to be recycled and for the rest incineration was assumed. About $80 \%$ to $90 \%$ of rock wool waste $\left(0.5 \mathrm{~kg} \mathrm{~m}^{-2}\right)$ is taken back by the manufacturer to be mixed with peat for manufacturing horticultural compost or used as an inert material for embankment works.

"Green waste" consisting of pruning waste and the plants at the end of the season amounts to about $17 \mathrm{~kg} \mathrm{~m}^{-2}$ for soilless cultivation and $13 \mathrm{~kg} \mathrm{~m}^{-2}$ for soil-grown crops. Composting is complicated by the fact that the organic waste is mixed with plastic twine and clips, so it is sent to landfill (30\%), burned or, more rarely, incorporated into the soil for field crops.

For soilless cultivation ( $80 \%$ of the total area), $31 \%$ of nitrates and $48 \%$ of potassium is leached (Sedilot et al. 2002). Emissions of nitrate, ammonia, nitrous oxide and other nitrogen oxides were estimated from recommendations given by Audsley (1997) and IPCC (1997). Leached potassium was considered to come from unused potash amendments. For soil-grown crops, based on experimental data it was assumed that $20 \%$ to $30 \%$ of fertiliser inputs are released into the environment. For nitrogen, $\mathrm{N}$ fertilisation roughly equals the $\mathrm{N}$ exported in the crop (Lecompte et al. 2008). As a consequence, $\mathrm{N}$ losses are dependent on $\mathrm{N}$ mineralization, which supplies the excess $\mathrm{N}$ in the 
balance. Assuming a mean $\mathrm{N}$ mineralization rate of $0.75 \mathrm{~kg} \mathrm{Nha}^{-1} \mathrm{day}^{-1}$ in tunnels during the tomato cropping period, $\mathrm{N}$ losses can be equated to $28 \%$ of $\mathrm{N}$ inputs.

\subsection{Outline of LCA principles applied to greenhouse} tomato production

LCA is divided into four parts (ISO IOFS 2006): goal, inventory analysis, impact assessment and interpretation. Rather than present all its principles, which can be found in Jolliet et al. (2005), we will stress its specific aspects for greenhouse and tunnel production.

\subsubsection{Boundaries of the system and functional unit}

The function of the systems studied is to produce fresh tomatoes and it follows that the selected functional unit is the $\mathrm{kg}$ of fresh tomato. The system boundary (Fig. 1) is defined at the farm gate and it incorporates the following processes: (1) extraction and preparation of the raw materials and energy used for infrastructure and production, (2) manufacture of structures and equipments, (3) transport of system inputs, i.e. $20 \mathrm{~km}$ for all inputs, except $150 \mathrm{~km}$ for glasshouses in the north-west and plastic houses and tunnels in the south-east and 1,200 km for glasshouses in the south-east and plastic houses in the north-west, (4) disposal of production waste and structures at the end of the activity, (5) tomato packaging but not transport.

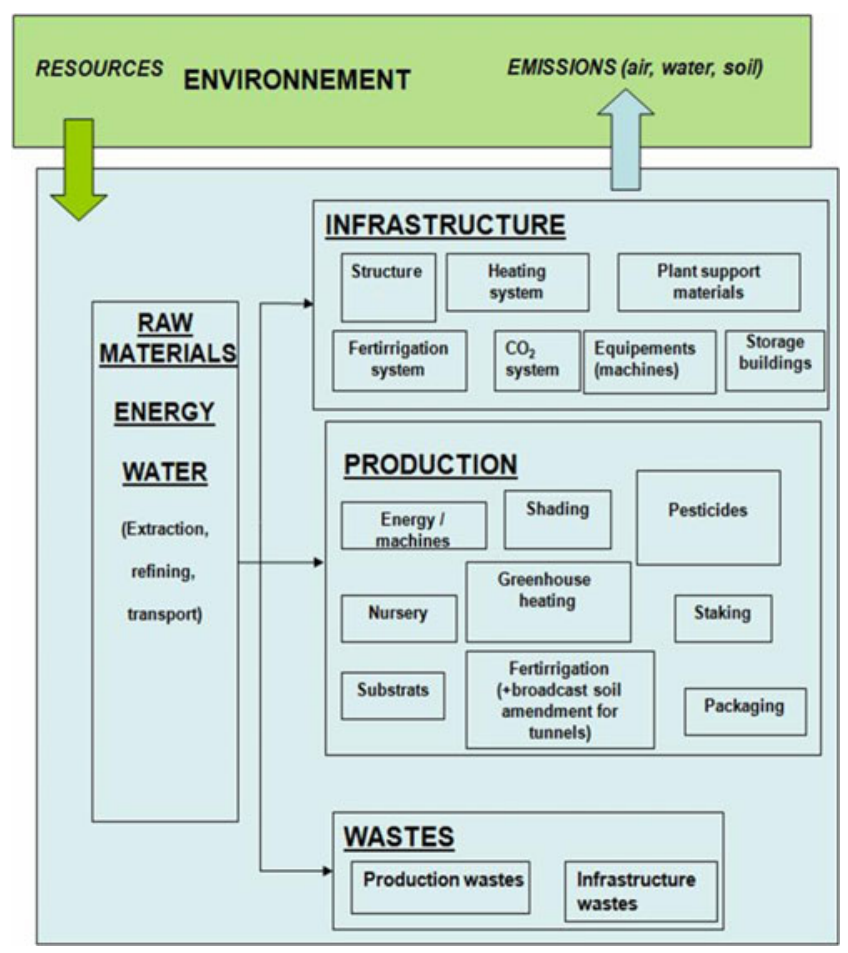

Fig. 1 Boundaries of the studied tomato production system under cover (in blue) and included sub-systems

\subsubsection{Life cycle impact assessment}

LCA was performed using a mid-point approach and the following impact categories were considered:

- Fossil non-renewable energy (FEN) in MJ eq using Cumulative Energy Demand method (Frischknecht et al. 2003).

- Nuclear non-renewable energy (NEP) in MJ eq using Cumulative Energy Demand method (Frischknecht et al. 2003).

- Global warming potential (GWP 20 years) in $\mathrm{kg} \mathrm{CO}_{2}$ eq using the Intergovernmental Panel on Climate Change estimate (IPCC 2001).

- Photochemical ozone formation (POF) in g ethylene eq using the environmental design of industrial products (Hauschild and Wenzel 1998).

- Eutrophication (EP) in $\mathrm{g} \mathrm{NO}_{3}$ using the environmental design of industrial products (Hauschild and Wenzel 1998).

- Acidification (AP) in $\mathrm{g} \mathrm{SO}_{2}$ using the environmental design of industrial products (Hauschild and Wenzel 1998).

- Ozone layer depletion (ODP) in kg CFC-11 eq using CML01 (Guinée et al. 2001).

- Terrestrial ecotoxicity (TTP) in kg 1.4-DB eq using CML01 (Guinée et al. 2001).

- Aquatic ecotoxicity (ATP) in kg TEG water using IMPACT $(2002+)$.

- Human toxicity (HTP) in kg 1.4-DB eq using CML01 (Guinée et al. 2001).

We have studied the toxicological impacts (ATP, TTP and HTP) of pesticides separately from the other subsystems to focus specifically on the consequences of greenhouse confinement for pesticide transfers.

\subsection{Specific aspects of LCA for greenhouse and tunnel} production

\subsubsection{Allocation of costs to co-products}

In tunnel systems the tomatoes are produced in rotation with salad crops, hence the costs have to be allocated to each co-product. A functional approach (Audsley 1997) has been considered for each subsystem involved in tunnel production. Agricultural machinery was allocated according to duration of use ( $13 \%$ to $25 \%$ for tomato). For soil amendments, the allocation was based on the mineral exports of each crop $(75 \%$ of the total for tomato). An economic approach based on yearly sales of each product was used for tunnel structures $(48.4 \%$ for tomato). 


\subsubsection{Assessing the toxicological impacts of plant protection in protected horticulture}

Inside greenhouses, pesticide transfer is quite different from that in field cropping conditions, which has two important consequences: (1) it limits transfer of pesticides and decreases their impacts at the regional level and (2) workers in greenhouses are severely exposed. For these reasons, but also due to the lack of a standard method for calculating pesticide emissions from greenhouses, we estimated the toxicity caused by pesticide applications separately from the other toxicological effects. However, the impacts from pesticide production have been considered together with the inputs, separately from its application. The first step in the fate of pesticides applied in protected horticulture, the transfer from the greenhouse into the environment, is not included in the standard methods, for example USES-LCA. To estimate the emissions we used the model developed by Hauschild (2000) and adapted by Antón et al. (2004) to greenhouse conditions. The model estimates the fraction of active ingredient emitted from the greenhouse, taking into account the loss via the leaching $\left(f_{\text {leaching }}\right)$, due to drift $\left(f_{\text {drift }}\right)$ and the loss via volatilisation from soil and plant $\left(f_{\text {soil } \rightarrow \text { air }}, f_{\text {plant }} \rightarrow\right.$ air $)$ using an initial dispersion between plant $\left(f_{\text {gh-plant }}\right)$ and soil $\left(f_{\text {gh-soil }}\right)$ based on the leaf area index. We decided to ignore the leaching fraction as in the greenhouses the soil is covered by plastic or concrete. In consequence the loss is given as:

$f_{\text {gh-env }}=f_{\text {drift }}+f_{\text {soil } \rightarrow \text { air }}+f_{\text {plant } \rightarrow \text { air }}$

The allocation of the volatised fraction to the soil and aquatic ecosystem are estimated as being equal to those of Antón et al. (2004), assuming that $95 \%$ is deposited on the soil and $5 \%$ reaches the aquatic ecosystem.

The data used to calculate the initial dispersion and volatilisation are summarised in Tables 3 and 4. The characterization factors were taken from Hayer and Gaillard (2010) who calculated toxicity potentials for 320 active ingredients (A.I.) for the impact categories ATP, TTP and HTP. The SYNOPS database (Gutsche and Strassemeyer 2007) served as reference, data gaps for physico-chemical properties and toxicity figures being filled with the help of the Footprint PPDB (2007). For AIs that could not be characterised in this way, the median of 320 AIs as given by Hayer and Gaillard (2010) was used to estimate the effect. The toxicity potentials calculated with USES-LCA are highly uncertain (Huijbregts et al. 2000) especially for heavy metals like copper. Also the calculation of pesticide emissions from greenhouses has a high level of uncertainty due to both the assumptions about the daily evaporation rates of active ingredients from plants and soil and the input data for the half-life of the given active ingredients. This implies that the results should be regarded as a relative comparison. Nevertheless we studied three scenarios for the pesticide emissions to analyse if the assumptions will change the results. These scenarios are:

Scenario 1 Initial emission compartments were soil and water for $95 \%$ and $5 \%$ of the active ingredients were lost via drift and volatilization.

Scenario 2 Initial emission to soil for the complete mass of all active ingredients

Scenario 3 Initial emission to air for the complete mass of all active ingredients

Furthermore the results for these scenarios will be presented with and without the impact of copper sulphate, to verify if this substance, dominating the impacts, affects the conclusions.

\subsubsection{Sensitivity analysis with respect to energy consumption variations}

Our input data for each specific scenario of production corresponds to mean values. However, the distribution of the individual input data can be more or less scattered or grouped around the mean and consequently the mean computed impact factors for different scenarios can be more or less significantly different from each other. As we entered approximately, 200 input data for each studied tomato production scenario, we cannot study the sensitivity of the impact factors for all the input data, particularly because we rarely have data for evaluating their distribution around the mean value. Nevertheless, we shall see later that a single input, the heating energy, explains between $50 \%$ and $90 \%$ of the impact for almost all the impacts for the heated scenarios. Consequently we performed a sensitivity analysis of the energy consumption, first because this input is crucial and secondly because, thanks to a nationwide study on 130 tomato greenhouses (Vésine et al. 2007), we know its statistical distribution round the mean (Table 2). Therefore, we first evaluated the impacts deduced from the mean value of the heating consumption for each production scenario and then considered the same evaluation but with the mean value plus or minus the standard deviation of the heating consumption. Next, we verified whether the confident intervals of the impacts for the different scenarios were significantly different from each other.

\section{Results and discussion}

\subsection{System comparisons}

A summary of the impacts in the different production systems is given in Table 5. It is immediately obvious that 


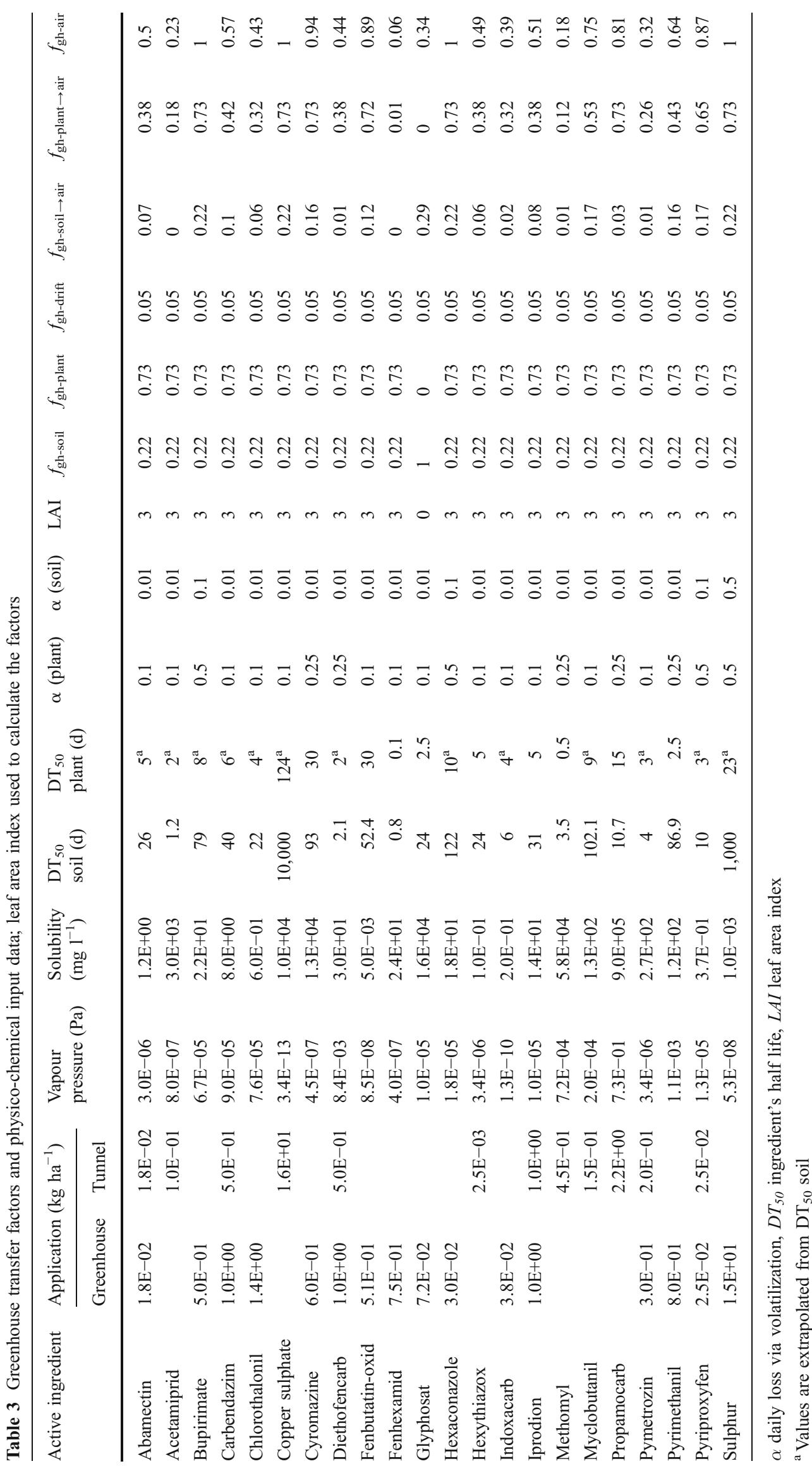




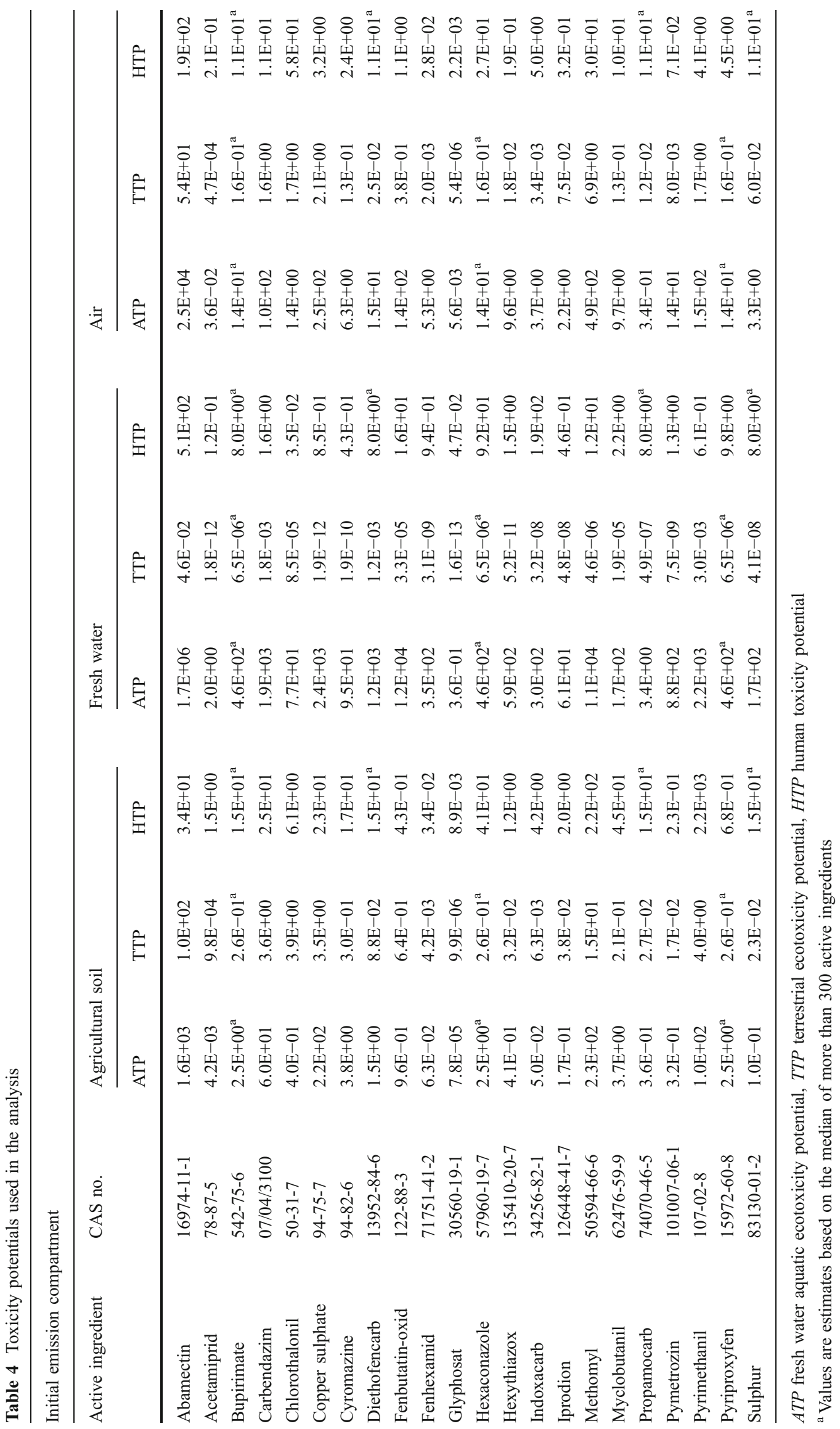




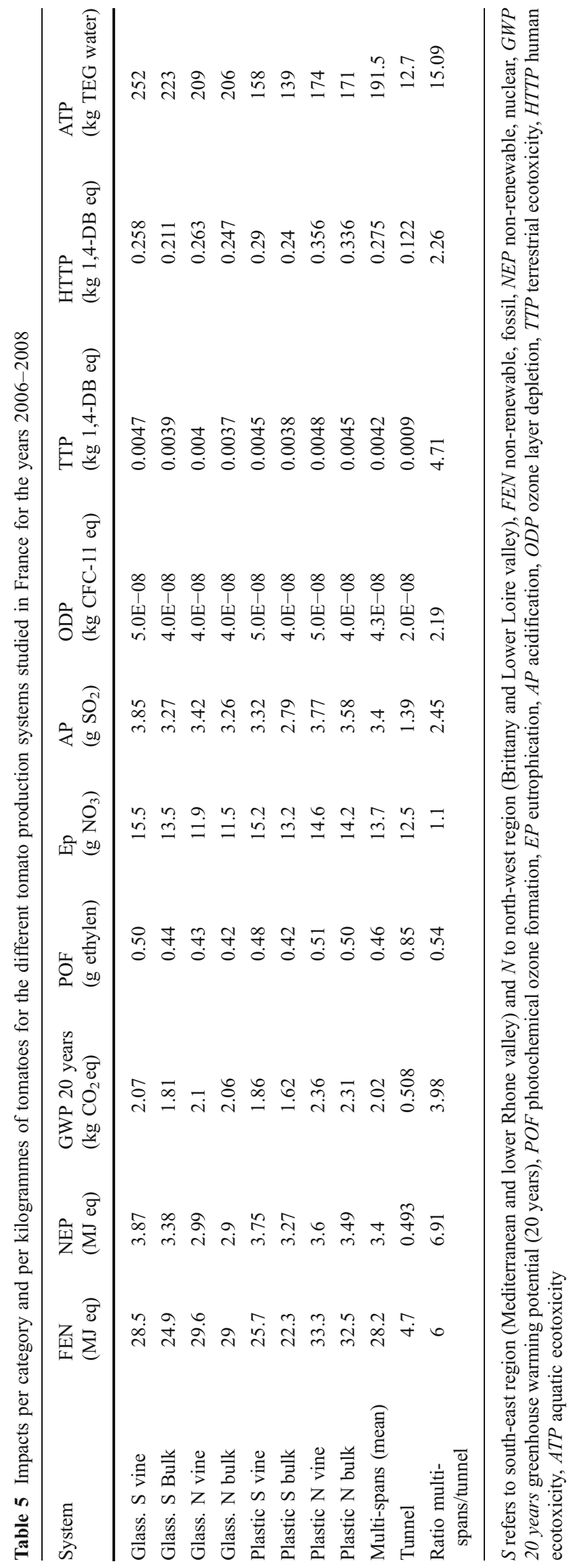

the cost of tomato production is significantly lower in tunnels than in multi-spans, on average 4.5 times less when the impacts are studied per kilogrammes of tomatoes produced (Table 5). For Aquatic Toxicity, the impact of tunnel production is 15 times lesser. The only impact which is higher in tunnels is POF. Despite quite different watering and fertilisation practices, tunnels (soil cultivation) and multi-spans (soilless cultivation) exhibit a quite similar eutrophication impact.

The kilogramme of tomato produced has been used as the functional unit to express impacts. However, one can hardly compare tomatoes produced in February with those produced in July (for the northern hemisphere) because the former are much more difficult to obtain and require incomparably more resources than the latter. Moreover, this functional unit does not take differences in tomato quality (for example between on-the-vine and cherry tomato types) into account. It even makes it disadvantageous to improve quality because this invariably reduces yields. Dividing the impacts per $\mathrm{kg}$ of tomatoes by the selling price (euros per kilogramme, see Table 2), the impact can be expressed per euro of tomatoes produced. Using this functional unit generally reduces on average by about $25 \%$ the increase in impact when switching from tunnels to heated greenhouses (Table 6). However, it does not eliminate the huge impact difference between the two systems.

Tables 7 and 8 give a more precise analysis of the relative impact contributions of infrastructure, production and waste, for production under glasshouse and under plastic in a given region. As the results for heated greenhouses (glass or plastic) are rather similar with one another, we have only presented the detailed results for only the production of on-the-vine tomatoes in glasshouses in the south-east (Table 7).

Between $80 \%$ and $95 \%$ of the total impact is due to the production sub-system, greenhouse heating being the major contributor, not only to non-renewable fossil energy impact but to all the impacts, except for Photochemical Ozone Formation and Eutrophication. For tunnels, the production sub-system represents $81 \%$ of the total impact but there is zero contribution from heating except for nursery heating before planting (Table 8).

The influence of major determinants of heated tomato production was studied. We checked for contrasts emerging from comparisons of the nature of the cladding material (glass vs plastic), the region of production (north vs south) or the type of tomato (bulk vs on the vine). As heating energy had a major influence on the impacts, the variability of energy consumption was taken into account in this analysis. First, a confidence interval around the mean for heating energy was calculated in each case. Then, three LCAs were performed with these mean and the upper and 
lower limits of the confidence interval. The results are given in Table 9. Variations in heating consumption gave an uncertainty of $6-7 \%$ for FEN and GWP, and less than 5\% for the other impacts. The lower energy consumption per square metre in the south lowered the FEN and GWP impacts by $18.5 \%$ and $16.5 \%$, respectively. This reduction would have been even higher if yields had not been reduced in the south due to insufficient climate control in summer. The lower energy use can also explain the reduced impacts on HTP in the south. As aluminium (used with glass in glasshouses) is more often and completely recycled than steel, glasshouses generally had less impact than plastic multispans (Table 9). However, aluminium is the major contributor to aquatic toxicity (ATP), which explains why this specific impact is $40 \%$ higher for glasshouses. Bulk tomato production always had less impact than on-the-vine production due to the combination of higher yields and simpler packaging.

\subsection{Energy consumption and global warming potential}

Heating crops by natural gas contributed $85 \%$ of the 28.5 MJ eq $\mathrm{kg}^{-1}$ used as non-renewable fossil energy (Table 7), while energy demand in the tunnel system was only 4.7 MJ eq $\mathrm{kg}^{-1}$ (Table 8). Half of this energy in tunnels is being used for heating nursery production, $22 \%$ for bulk tomato packing and $16 \%$ for tunnel structure manufacture. $84 \%$ of NEP was used for electricity production to run the boilers in glasshouses. NEP consumption in tunnels was only $13 \%$ of that calculated for greenhouses. As electricity in France is produced mainly by nuclear energy, the main substance concerned in NEP is uranium ( $95 \%$ to $99 \%$, Table 10). GWP depended on heating crops, which caused $80 \%$ of the $2.07 \mathrm{~kg} \mathrm{CO}$ eq $\mathrm{kg}^{-1}$ (Table 7). The greenhouse structure, the second most important contributor, was the source of $5.7 \%$ of the total GWP. Main contributing emissions were $\mathrm{CO}_{2}$ (68 to $81 \%)$ and $\mathrm{CH}_{4}$ (14\%). Tunnel impacts were much smaller (Table 8 ) and predominantly linked to the heating in the seedling nursery (34\%) and the burning of plastic waste $(22 \%)$.

Values of energy use calculated in this study were compared to other data from the literature (Table 11). The approximate total energy use for multi-span tomato production in France (31.6 MJ eq kg-1), Switzerland (22 to $38 \mathrm{MJ}$ eq $\mathrm{kg}^{-1}$; Jolliet 1993), and north-east USA (49.3 MJ eq $\mathrm{kg}^{-1}$; NYSERDA 2009) is comparable, although the high value for north-east USA can be explained by its much more severe winters. This is also confirmed by comparing the GWP impacts for glasshouse production in France $\left(2.02 \mathrm{~kg}\right.$ eq $\left.\mathrm{CO}_{2} \mathrm{~kg}^{-1}\right)$ and the Netherlands (2.47 kg eq $\mathrm{CO}_{2} \mathrm{~kg}^{-1}$; Pluimers et al. 2000). However, comparing the energy use cited by Stanhill 


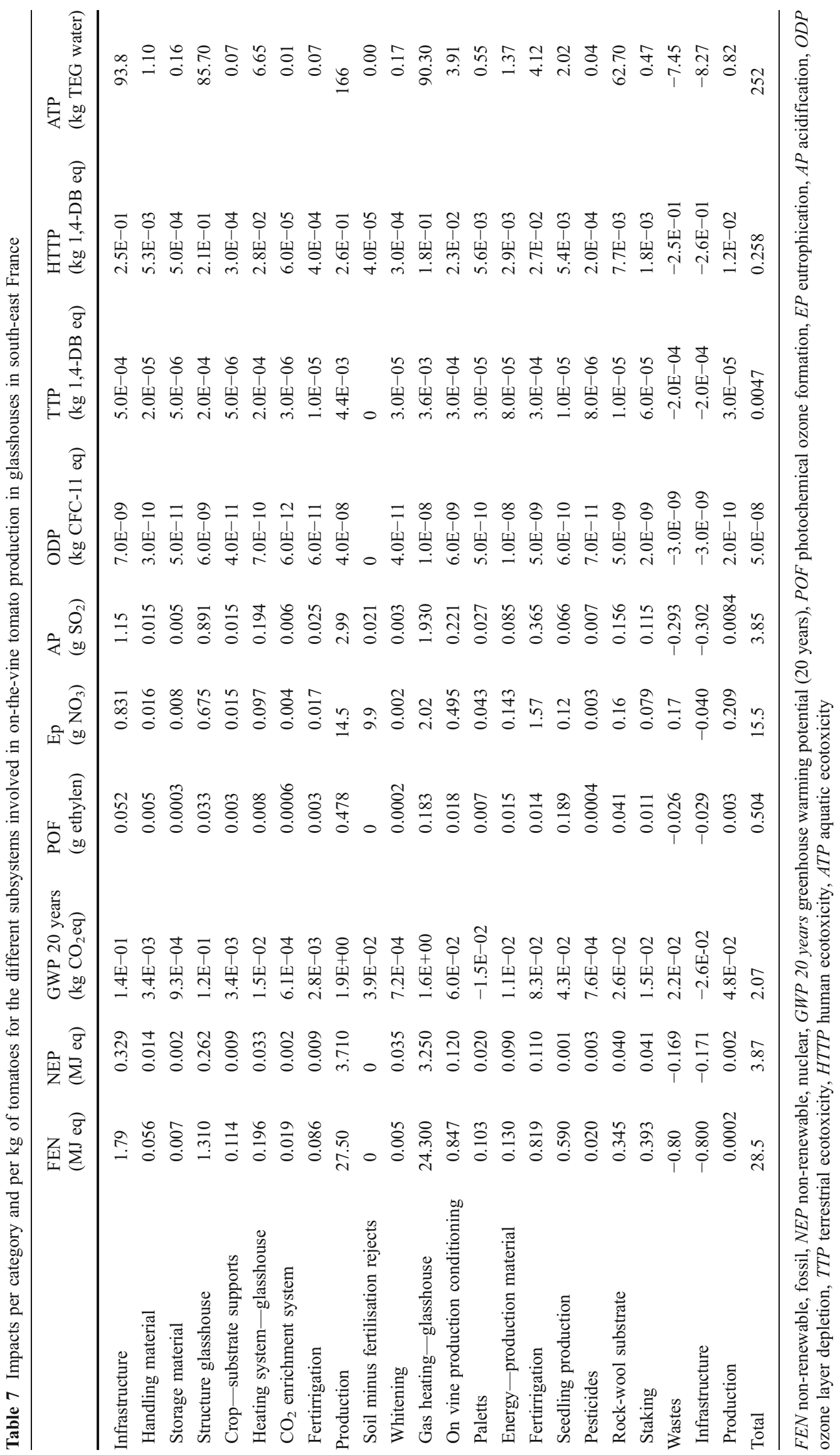




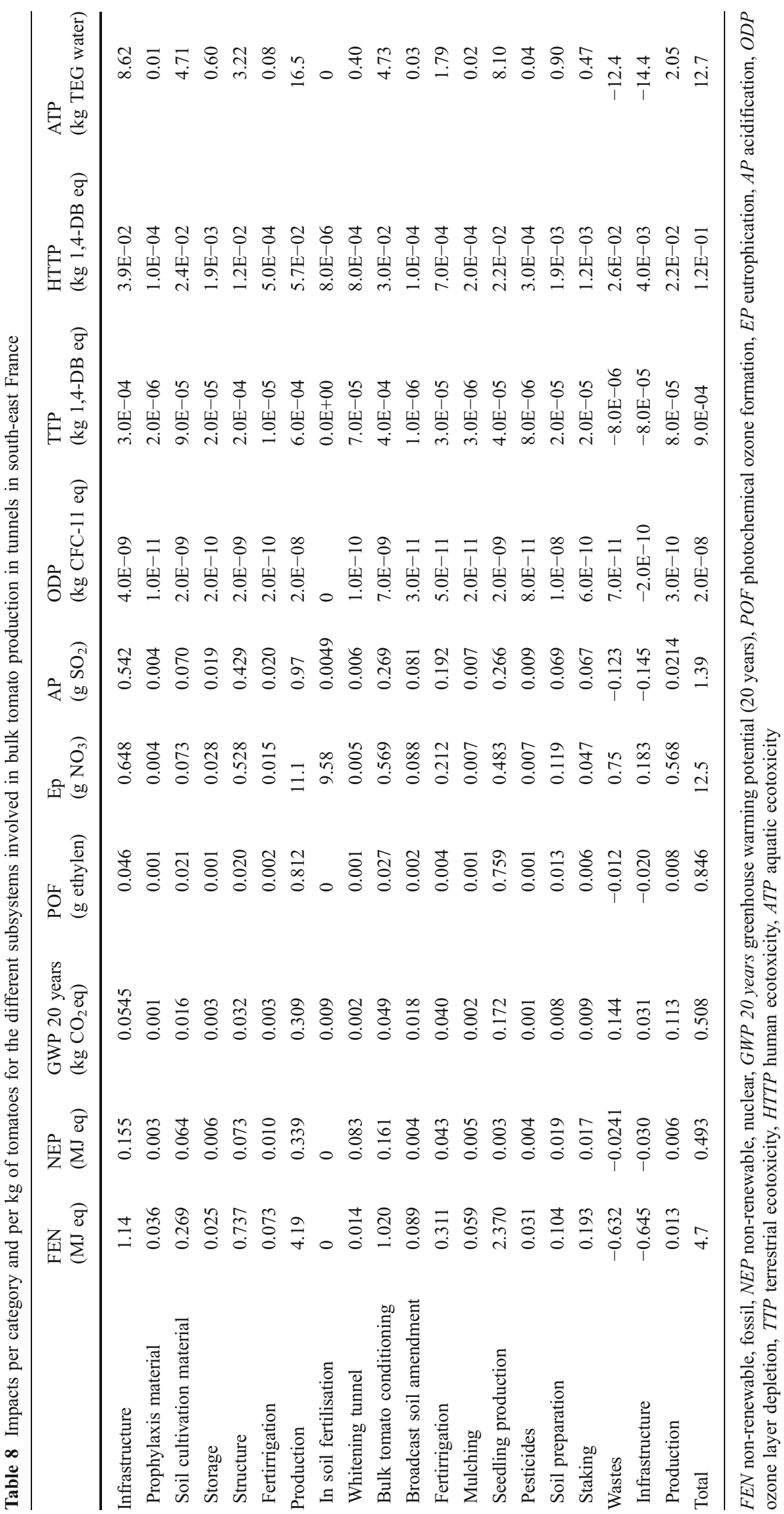




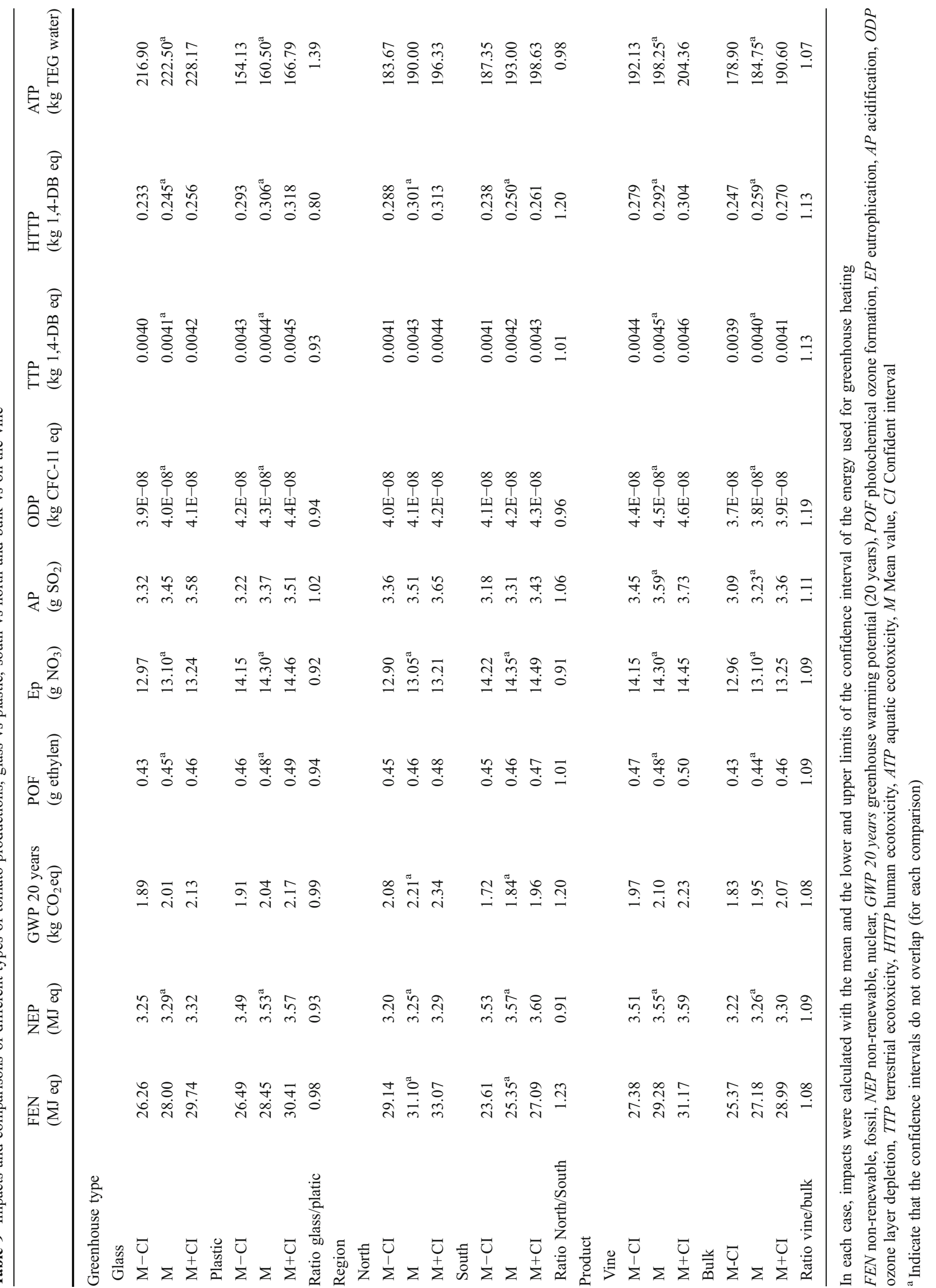


Table 10 Main substances contributing to the different impact categories for the three main tomato production scenarios in the south of France (\% of total impact for each category)

\begin{tabular}{|c|c|c|c|c|}
\hline & Percent & Tunnel & Glasshouse bulk (S) & Plastic house bulk (S) \\
\hline \multirow[t]{3}{*}{ Non-renewable fossil energy } & Natural gas & 68.6 & 90.7 & 91.4 \\
\hline & Oil & 16.1 & 4.8 & 4.4 \\
\hline & Coal & 5.7 & 2.4 & 1.6 \\
\hline \multirow[t]{5}{*}{ Non-renewable nuclear energy } & Uranium & 95.5 & 98.7 & 99.7 \\
\hline & GWP 20 years & & & \\
\hline & $\mathrm{CO}_{2}$ & 68 & 81.2 & 80.6 \\
\hline & $\mathrm{CH}_{4}$ & 14.4 & 14.4 & 14.3 \\
\hline & $\mathrm{N}_{2} \mathrm{O}$ & 6.1 & 3.7 & 4.1 \\
\hline \multirow[t]{4}{*}{ Photo-chemical ozone formation } & Aromatic hydrocarbons & 86.3 & 38.4 & 40.1 \\
\hline & NMCOV & 7.8 & 40.3 & 37.6 \\
\hline & $\mathrm{CO}$ & 2.3 & 12 & 13.1 \\
\hline & $\mathrm{CH} 4$ & 1 & 5.9 & 4.5 \\
\hline \multirow[t]{4}{*}{ Eutrophication } & Phosphate in soil and water & 62.8 & 44.9 & 46.1 \\
\hline & Nitrogen in water & 17.7 & 29.7 & 30.4 \\
\hline & $\mathrm{NO}_{x}$ & 10.1 & 20.2 & 18 \\
\hline & $\mathrm{NH}_{3}$ in air & 4.1 & 2.95 & 3.3 \\
\hline \multirow[t]{5}{*}{ Acidification } & $\mathrm{NO}_{x}$ & 47.4 & 43.4 & 44.3 \\
\hline & $\mathrm{SO}_{2}$ & 26.4 & 24.6 & 20 \\
\hline & $\mathrm{NH}_{3}$ air & 19.2 & 6.3 & 8.2 \\
\hline & $\mathrm{HCl}$ & 3.3 & 1.2 & 1.3 \\
\hline & $\mathrm{SO}_{x}$ & 2.3 & 24.1 & 25.6 \\
\hline \multirow[t]{2}{*}{ Ozon layer depletion } & Halon & 90.8 & 94.3 & 92.9 \\
\hline & CFC (10.12.114) & 8.7 & 5.1 & 6.2 \\
\hline \multirow[t]{4}{*}{ Terrestrial ecotoxicity } & Chrome in soil & 22.3 & 49.2 & 53.5 \\
\hline & Mercury in air and water & 32.8 & 36.9 & 33.8 \\
\hline & Vanadium in air & 16.2 & 5.8 & 5.2 \\
\hline & Arsenic in air & 5.2 & 2.3 & 2.3 \\
\hline \multirow[t]{9}{*}{ Human toxicity } & Chrome VI in air & 16.4 & 14.1 & 8.8 \\
\hline & HAP in air & 11.1 & 37.3 & 46.7 \\
\hline & Barium in water & 10.5 & 4.3 & 3.4 \\
\hline & Arsenic in air & 8.1 & 9.2 & 7.9 \\
\hline & Barite in water & 7.3 & 2.3 & 1.8 \\
\hline & Acenaphthylen in water & 7.1 & l & / \\
\hline & Antimony in water & 5.2 & 1.5 & 1.4 \\
\hline & Benzene in air/water & l & 9.6 & 7 \\
\hline & Nickel & 1 & 3.9 & 7.8 \\
\hline \multirow[t]{5}{*}{ Aquatic ecotoxicity } & Aluminium in air/water/soil & 106 & 95.2 & 93.9 \\
\hline & Aromatic hydrocarbons in air & 17.9 & / & l \\
\hline & Antimony in water & 5.9 & / & / \\
\hline & Cooper in water/soil & -33.1 & 3.5 & 3 \\
\hline & zinc & -7.8 & / & / \\
\hline
\end{tabular}

(1980) for glasshouse tomato production in southern England (125 MJ eq kg-1) with the results obtained in this study or those published for Switzerland (about $30 \mathrm{MJ}$ eq $\mathrm{kg}^{-1}$; Jolliet 1993), energy costs were found to be four times higher for the former (Table 11). Despite the difference in these two values, this is consistent both with the considerable energy savings obtained during the energy crisis of the $80 \mathrm{~s}$ (an approximate halving of energy use per square metre) and with the major yield increase of the past 30 years (a doubling of yield per $\mathrm{m}^{2}$ ). Still, this does not 
Table 11 Comparison of energy production (MJ eq) and GWP ( $\mathrm{kg} \mathrm{eq} \mathrm{CO}_{2}$ ) needed to produce $1 \mathrm{~kg}$ of bulk tomato for different production systems, countries and times

\begin{tabular}{|c|c|c|c|}
\hline Systems & Sources & Total energy (MJ eq) & GWP $\left(\mathrm{kg}\right.$ eq $\left.\mathrm{CO}_{2}\right)$ \\
\hline Multi-spans (mean), France, $\mathrm{CO}_{2}$ enrichment & This study & 31.6 & $2.02^{\mathrm{a}}$ \\
\hline Glasshouses, USA, $\mathrm{CO}_{2}$ enrichment & NYSERDA (2009) & 49.3 & - \\
\hline Glasshouses, Swiss, $\mathrm{CO}_{2}$ enrichment & Jolliet (1993) & $22-38$ & - \\
\hline Glasshouses, the Netherlands, $\mathrm{CO}_{2}$ enrichment & Pluimers et al. (2000) & - & $2.47^{\mathrm{b}}$ \\
\hline Glasshouses, England, $\mathrm{CO}_{2}$ enrichment & Williams et al. (2006) & 130 & $9.40^{\mathrm{b}}$ \\
\hline Glasshouses, England, $\mathrm{CO}_{2}$ enrichment & Stanhill (1980) & 125 & - \\
\hline Cold tunnel, France, no $\mathrm{CO}_{2}$ enrichment & This study & 5.2 & $0.51^{\mathrm{a}}$ \\
\hline Cold plastic house, Spain, no $\mathrm{CO}_{2}$ enrichment, soil less cultivation & Antón et al. (2005) & - & $0.09^{\mathrm{a}}$ \\
\hline Cold plastic house, Spain, no $\mathrm{CO}_{2}$ enrichment, in soil cultivation & Antón et al. (2005) & - & $0.12^{\mathrm{a}}$ \\
\hline Cold plastic house, Turkey, no $\mathrm{CO}_{2}$ enrichment & Canakci and Akinci (2006) & 2.5 & - \\
\hline
\end{tabular}

For the Netherlands, the results were calculated from Pluimers et al. (2000) data and based on an estimated average glasshouse tomato yield of $45 \mathrm{~kg} \mathrm{~m}^{-2}$

GWP greenhouse warming potential

${ }^{a}$ GWP 20 years $\left(\mathrm{kg}\right.$ eq $\mathrm{CO}_{2}$ )

${ }^{\mathrm{b}} \mathrm{GWP} 100$ years $\left(\mathrm{kg}\right.$ eq $\left.\mathrm{CO}_{2}\right)$

explain the fourfold difference in the figure for the present total energy use and GWP impacts in England given by Williams et al. (2006). For cold cropping, there are clear differences in FEN between cold tunnels in France (4.7 MJ eq $\mathrm{kg}^{-1}$ estimated in this study) and cold plastic houses in Turkey (2.5 MJ eq $\mathrm{kg}^{-1}$; Canakci and Akinci 2006.), and for GWP between cold tunnels in southern France $\left(0.5 \mathrm{~kg}\right.$ eq $\mathrm{CO}_{2} \mathrm{~kg}^{-1}$, this study) and cold plastic houses in Spain (0.12 kg eq CO $\mathrm{kg}^{-1}$; Antón et al. 2005). However, it seems that nursery heating, which is the main energy consumer for tunnels in France, was not considered in either the Spanish or Turkish studies. A recent trend to use grafted tomato seedlings with lower plant density for cold tunnels could reduce the impact of the nursery period.

\subsection{Impacts other than ecotoxicity}

Seedling production was responsible for a large percentage of the POF in both greenhouses and tunnels (Tables 7 and 8). However, as plant densities are higher in tunnels, the impacts were higher. For greenhouse systems, heating contributed $36 \%$ of the impacts on POF. The main substances contributing to POF were aromatic hydrocarbons and non-methane volatile organic compounds (NMVOC) (Table 10). Comparable eutrophication levels were observed for soilless and soil-grown systems. It was caused either by drainage of the excess solution (multispans) or by excess soil fertilisation (tunnels). The main contributing substances were phosphate, nitrate and $\mathrm{NO}_{x}$ (Table 10). Switching from a soilless system without drainage recycling to a soilless system with recycling reduced the eutrophication potential by $40 \%$ in Spanish conditions (Antón et al. 2005). As it does not necessitate major modifications, one can expect, as a first approximation, a similar reduction for soilless cultivation in France. The lack of recycling systems in soilless production in France is specific to tomatoes, as with other crops such as roses the fertigation water is commonly recycled. The main reason for this is the difficulty of controlling both sanitary conditions and mineral concentration drift in the recycled solution over long periods, particularly when the water is rich in poorly absorbed minerals which accumulate in the solution ( $\mathrm{Na}, \mathrm{Ca}$, etc.). Antón et al. (2005) also found a decrease of $40 \%$ in eutrophication impact when switching from soil to soilless tomato production in Spain. Our results however reveal a moderate increase when switching from cold tunnel soil cultivation to soilless heated multi-span systems (11.6 against $13.3 \mathrm{~g} \mathrm{NO}_{3}{ }^{-}$eq). However, a major part of this increase is due to $\mathrm{NO}_{x}$ emissions to air caused by greenhouse heating ( $\left.2.02 \mathrm{~g} \mathrm{NO}_{3}{ }^{-} \mathrm{eq}\right)$.

Acidification was three times higher on average for heated greenhouses than for tunnels (Table 5). Emissions from combustion $\left(\mathrm{NO}_{x}, \mathrm{SO}_{2}\right)$ were the main contributors to the total impact. This is why in multi-span systems, heating $(50 \%)$ followed by manufacturing of the structure $(17 \%)$ were the main processes causing AP (Table 7), whereas in the tunnel system the structure (31\%), seedling production and packaging (both 20\%) were the processes with the highest energy demand and consequently were the main contributors to AP. Though heating contributed only $20 \%$ of the total impact, ODP was about twice as high for heated greenhouse systems as for the tunnel system. In fact numerous techniques, characteristic of different levels of intensification, contributed to ODP: equipment operation 
$(20 \%)$, substrate production $(10 \%)$, etc. For tunnels, tillage $(50 \%)$ and tomato packaging $(27 \%)$ were chiefly responsible (Table 8). For all scenarios the main contributing substance $(>90 \%)$ was halon (Table 10$)$.

\subsection{Ecotoxic impacts}

\subsubsection{Impacts without pesticides}

As already stated, the impact of pesticide application was studied separately and was not included in the results in Tables 7 and 8 . In greenhouses, terrestrial ecotoxicity was four to five times greater than for tunnels because of the heating, which contributed $76-82 \%$ of the impact. Emissions of heavy metals, such as chromium and mercury, were the main causes of toxicity (Table 10). There was less difference between the tunnel and multi-span system for human toxicity than for ecotoxicity (Tables 7 and 8). Moreover, plastic houses had a higher impact (up to 1.5 times) than glasshouses. The main contributing substances were aromatic polycyclic hydrocarbons ( $37 \%$ to $47 \%$ ). Regarding aquatic toxicity, the 15 times higher impact in glasshouses was mainly caused by heating ( $40 \%$ of the impact), structure (30\%) and rock wool production (25\%). The main contributing substance was aluminium from the glasshouse structures (Table 10), which can dissolve in water in certain physical and chemical conditions. For all scenarios, recycling of structures had an important negative impact on TTP, HTP and ATP except for HTP in tunnels. Recycling aluminium and steel generated a positive impact for all the scenarios, particularly for aluminium glasshouses.

\subsubsection{Specific impacts of pesticides}

The toxicity potential of pesticides emitted from the multispan and tunnel systems are presented in Fig. 2. The impact of pesticide application per kilogrammes of tomatoes produced was five to 22 times higher in tunnels than in multi-spans. The differences were mainly caused by copper sulphate. For scenario 2 (active ingredients emitted to soil) and 3 (active ingredients emitted to air) the tunnel system still had a higher impact but differences were smaller, especially for the human toxicity in scenario 3 with a difference of only $3 \%$. Looking at the results without copper sulphate the outcome for scenario 1 gives the same picture but the impact of the applications in the tunnel was 1.5 to 2.5 times larger than that of the active ingredients applied in the multi-span system. For scenarios 2 and 3 the difference between systems nearly vanished for all the impact categories and the HTP in scenario 3 was even lower for the tunnel system. The results show that the initial emission scenario might affect the conclusion for the

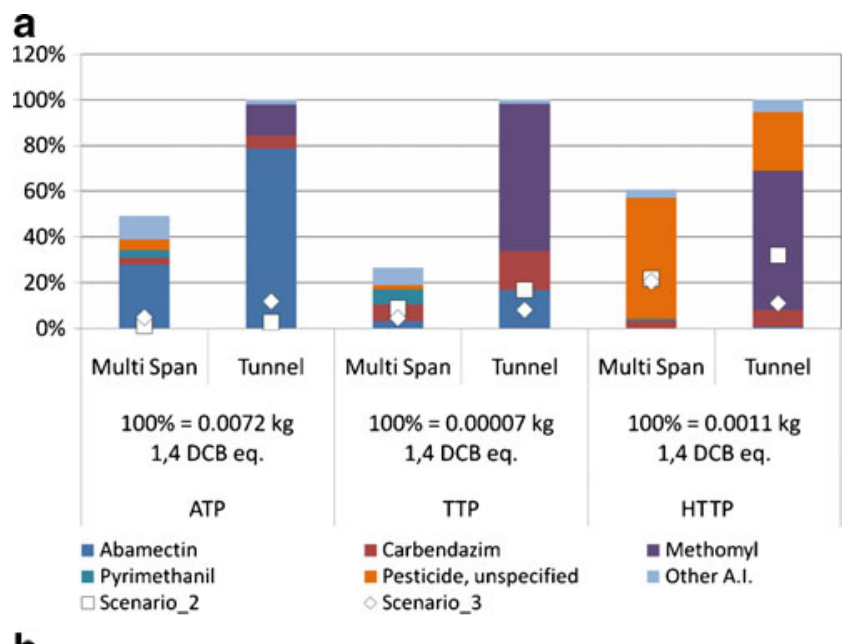

b

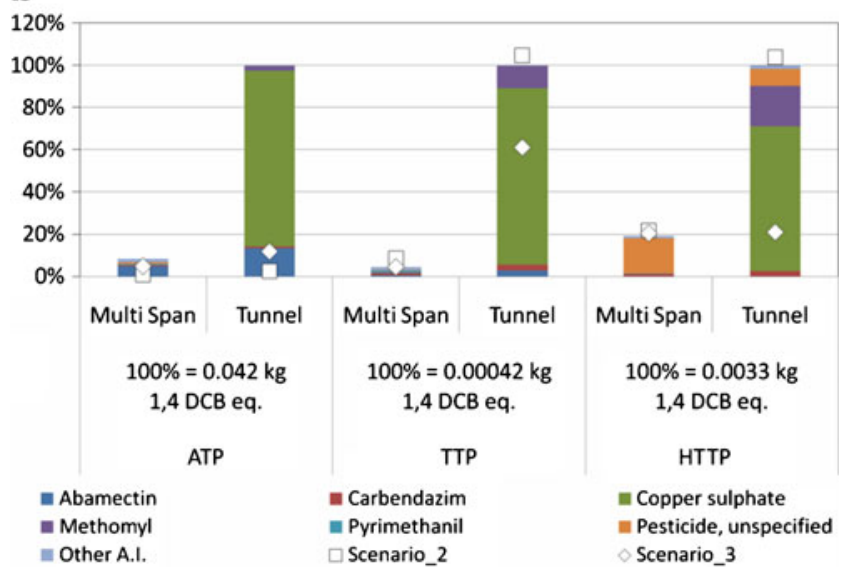

Fig. 2 Aquatic ecotoxicity, terrestrial ecotoxicity and human toxicity per kilogrammes of tomatoes according to USES-LCA with (a) and without (b) the impact of copper sulphate. Impacts are presented relative to the tunnel system for each impact category. The bars represent the detailed results for scenario 1; the dots the total impact calculated for scenarios 2 and 3. All pesticides which could not be characterised (see Table 2) are summarised as pesticide unspecified. TTP terrestrial ecotoxicity, HTTP human ecotoxicity, ATP aquatic ecotoxicity

toxicity impact categories, but in this study for the three scenarios the tunnel system had a higher impact for all toxicity impact categories. Even though the calculation of pesticide emissions might cause a substantial uncertainty, the results indicate that the active ingredients applied in greenhouses have a lower impact than the ones assumed to be used in the tunnel system. More generally, these results are in line with the spread of IPM practices in heated greenhouses and particularly the increasing use of dehumidification against fungi.

The comparison of pesticide application impacts with impacts for the rest of the production system (infrastructure, heating, etc.) showed that pesticides were of little importance (Fig. 3). The share due to pesticide application was negligible for multi-spans for all toxicity impacts $(\leq 0.36 \%)$. This is because of the huge impact of hydrocarbons emitted 


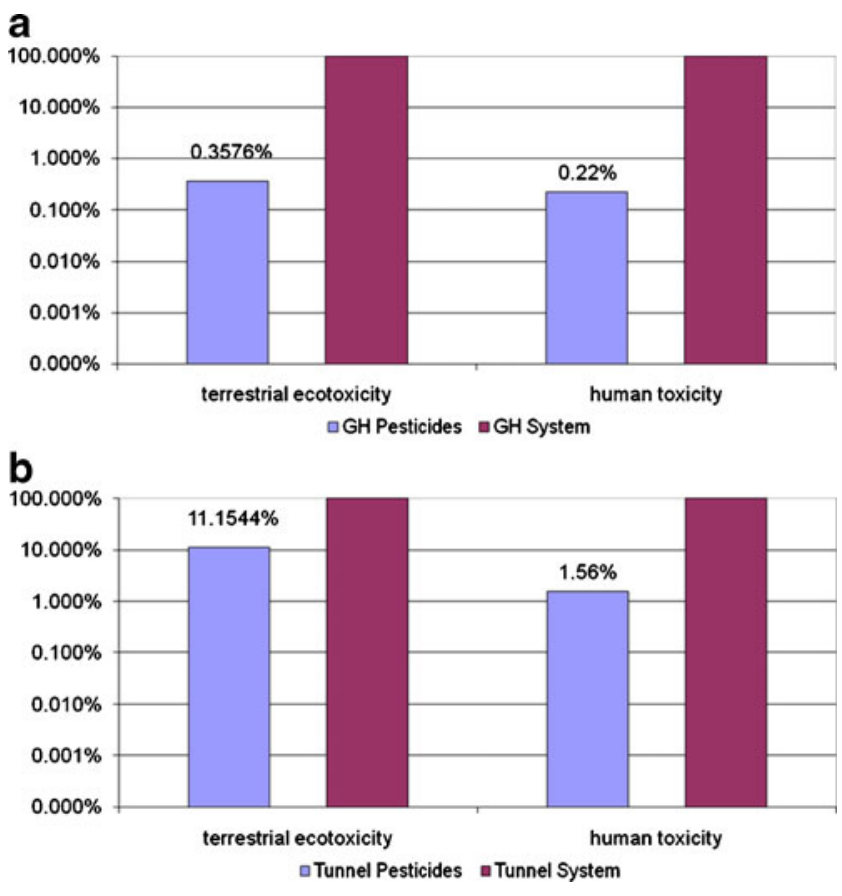

Fig. 3 Relative impacts of pesticides (scenario 1 and including copper sulphate) emitted from multi-span greenhouses (a) and tunnels (b) compared with the whole system (without pesticide application but including pesticide manufacture). Note the logarithmic progression of the ordinate scale and the omission of aquatic ecotoxicity because of the use of different methods for pesticides and system impact assessments

during heating, and also the reduced use of pesticides due to IPM practices. Air humidity control in heated greenhouses adds $20 \%$ to heating energy consumption and so has a considerable environmental impact. As the toxicological impact of pesticide application appears very low, plant health management through climate control has a greater impact than through fungicides. A similar estimation should be made for biological control, which also uses additional energy to assist the establishment of the reared natural enemies. For tunnels (Fig. 3b), pesticides represent a significant impact only for terrestrial ecotoxicity (11.15\%). More generally, whatever the type of shelter used, confinement of the pesticides inside the shelters is also responsible for this result because only the toxicological impacts of the pesticides that leave the greenhouse are assessed. LCA estimates impacts at the system boundaries whereas for protected crops, the pesticides remain largely confined to the greenhouse. Greenhouse workers (sprayers and re-entry workers) are thus directly and massively exposed to these toxic substances. This factor is not considered in an LCA approach.

\subsection{Seasonality of production and long distance transport}

Due to the free market in fresh vegetables, production can take place in countries with a mild winter climate, a long way from the country of consumption. This is the case between Spain or Morocco and northern Europe and, in America, between California or Mexico and north-eastern USA. Producing out-of-season fresh vegetables in these regions can save heating energy, but one must also consider the environmental impact generated by long distance transport. Reinhardt et al. (2008) and de Villiers et al. (2009) reported on energy investments for field tomatoes imported from Mexico into New York State compared to the same products grown locally in cold or heated greenhouses by considering the whole production chain, transport included. For locally grown tomatoes these authors established, as in our study, that "high tunnels have the distinct advantage over greenhouses in New York of lower production cost per unit of product, being more benign environmentally than greenhouses in terms of carbon dioxide emissions, and potentially being very local indeed".

They established that producing locally in heated greenhouses requires about $49.3 \mathrm{MJ} \mathrm{kg}^{-1}$ for out-of-season tomatoes and only $3.4 \mathrm{MJ} \mathrm{kg}^{-1}$ in unheated high tunnels for seasonal production whereas the trucking energy over the 4,000 km from Mexico into New York State needs $10 \mathrm{MJ} \mathrm{kg}^{-1}$ (road construction and maintenance were not considered). Although this study was not designed to tackle this question, we see that these figures are quite comparable to the French situation, with $31.6 \mathrm{MJ} \mathrm{kg}^{-1}$ on average for heating only for out-of-season tomatoes and $5.13 \mathrm{MJ} \mathrm{kg}^{-1}$ for seasonal unheated production, and distances between Paris (France) and the production areas of Agadir (southern Morocco) and Almeria (southern Spain) of 3,100 and $1,900 \mathrm{~km}$, respectively. If we assume that the trucking energy per kg transported is the same in Europe and North America, one finds 7.75 and $4.75 \mathrm{MJ} \mathrm{kg}^{-1}$, respectively, for transporting tomatoes from Agadir and Almeria to Paris. However, these are rough calculations that must be refined, particularly with a precise LCA of tomato production in Almeria and Agadir, together with consideration of sea transport and evaluation of the impacts of road construction and maintenance for road transportation.

\section{Conclusions}

The present LCA study of tomato production nationwide in France has enabled us to assess the environmental performance of the main protected cultivation systems and techniques designed for temperate countries. It has clearly established that greenhouse heating for off-season production generates the main impact for all the categories studied, including toxicology and ecotoxicology, the average impact per $\mathrm{kg}$ of tomato being 4.5 times greater for heated than for unheated crops. This conclusion is still valid for the impact per euro of tomatoes produced. Differences between 
various types of tomato production under heated greenhouse, or differences between regions are of lesser importance.

In this study, we paid particular attention to the toxicological and ecotoxicological impacts of plant health management. Regardless of the initial emission compartment and whether or not copper sulphate was considered, it was estimated that the toxicological impacts of pesticides, particularly fungicides, were lower in heated greenhouses than in cold tunnels. However, the impact of pesticide appeared to be a negligible part of the overall impact of the whole system, which is mainly determined by heating energy. The spatial scale of the toxicological assessment used with LCA does not make allowance for the confined character of greenhouses, where toxic exposure is very local indeed. Other approaches need to be considered and adapted to these specific conditions. These would include occupational indicators developed for evaluating the exposure of operators and workers to the active substances in plant protection products (Garreyn et al. 2003). The LCA should be combined with a risk assessment study of this kind for a complete environmental evaluation of the system.

Acknowledgements This work was carried out with the financial support of the French ANR-05-PADD-09, EcoSerre project for the years 2006-2008 and the European Network for durable exploitation of crop protection strategies (ENDURE) FP6-2005-FOOD-4-A project no. 031499 .

\section{References}

ADEME/FNCUMA. (2004) Gestion des films plastiques agricoles usagés: analyse des expériences existantes et des problèmes soulevés. ADEME-FNCUMA report, $116 \mathrm{pp}$.

Agreste (2008a) La tomate en 2007: bilan de campagne. Service des nouvelles des marchés, Minist. agriculture and fisheries. Available at: http://www.snm.agriculture.gouv.fr/bilan/tomate07.pdf

Agreste (2008b) Infos rapides-Légumes-Tomate-Septembre no 5/ 6. Available at: http://www.agreste.agriculture.gouv.fr

Agreste (2009) La tomate en 2008 : bilan de campagne. Service des nouvelles des marchés, Minist. agriculture and fisheries. Available at: http://www.snm.agriculture.gouv.fr/bilan/tomate08.pdf

Antón A, Castells F, Montero JI, Huijbregts M (2004) Comparison of toxicological impacts of integrated and chemical pest management in Mediterranean greenhouses. Chemosphere 54(8):12251235

Antón A, Montero JI, Munoz P (2005) LCA and tomato production in Mediterranean greenhouses. Int J Agr Resour Govern Ecol 4 (2): $102-112$

Audsley E (1997) Harmonisation of environmental life cycle assessment for agriculture. Final report, concerted action AIR3-CT94-2028. European Commission, DG VI Agriculture, $139 \mathrm{pp}$.

Canakci M, Akinci I (2006) Energy use pattern analyses of greenhouse vegetable production. Energy 31:1243-1256

Challa H, Bakker J (1998) Potential production within the greenhouse environment. In: Enoch Z, Stanhill G (eds) Ecosystems of the world. The greenhouse ecosystem. Elsevier, Amsterdam
Colino J, Martínez JM (2002) El agua en la agricultura del Sureste español. In: "La agricultura Mediterránea del siglo XXI".

de Villiers DS, Wien HC, Reid JE, Albright LD (2009) Energy use in tomato production: field, high tunnel and greenhouse compared for the northern tier of the USA. ISHS Greensys congress, Hotel Loews, Québec, Canada, June 14-19

Footprint PPDB (2007) The FOOTPRINT Pesticide Properties Database. Collated by the University of Hertfordshire as part of the EU-Funded FOOTPRINT project (FP6-SSP-022704). Available at: http://www.eu-footprint.org/ppdb.html. See also http://sitem.herts.ac.uk/aeru/footprint. University of Hertfordshire, Hertfordshire

Frischknecht R, Jungbluth N, Althaus H-J, Doka G, Dones G, Hischier R, Hellweg S, Humbert S, Margni M, Nemecek T, Spielmann M (2003) Implementation of Life Cycle Impact Assessment Methods. Ecoinvent report. Swiss Centre for Life Cycle Inventories, Dübendorf

Garreyn F, Vagenende B, Steurbaut W (2003) Harmonized environmental indicators for pesticides risk occupational indicators: operator, workers and bystander. Report financed by the EU sixth Framework Programme, contact number SSPEC-CT-2003-501977

Grasselly D, Hamm F, Quaranta G, Vitrou J (2009) Carbon footprint of coconut fibre (coir) substrates. Infos-CTIFL 249:55-59

Guinée J. (ed) (2001) Life cycle assessment: An operational guide to the ISO Standards, Final Report. Ministry of Housing, Spatial Planning and the Environment (VROM) and Centre of Environmental Science - Leiden University (CML)

Gutsche V, Strassemeyer J (2007) SYNOPS: ein Modell zur Bewertung des Umwelt-Risikopotentials von chemischen Pflanzenschutzmitteln. Nachrichtenbl. Deut. Pflanzenschutzdienst 59(9):197-210

Hauschild MZ (2000) Estimating pesticide emission for LCA of agricultural products. In: Weidema B, Moeusen M (eds), Agricultural Data for LCA, vol. 2. Agricultural Economic Research Institute, The Hague, pp 64-79

Hauschild MZ, Wenzel H (1998) Environmental assessment of products. 2: scientific background. 2. Chapman \& Hall, London

Hayer F, Gaillard G (2010) Aquatic and terrestrial ecotoxicity as well as human toxicity characterisation factors for pesticide emissions to soil according to the methods USES-LCA and EDIP. Available at: http://www.agroscope.admin.ch/oekobilanzen/01197/index. html?lang=de

Heijungs H, Guinée JB, Huppes G, Lankreijer RM, Udo de Haes HA, Wegener Sleeswijk A, Ansems AMM, Eggels PG, van Duin R, de Goede HP (1992) Environmental life cycle assessment of products: guide and backgrounds (Part 1). Centre of Environmental Sciences, Leiden

Hong SW, Lee IB, Hwang HS, Seo IH, Bitog JP, Yoo JI, Kim KS, Lee SH, Kim KW, Yoon NK (2008) Numerical simulation of ventilation efficiencies of naturally ventilated multi-span greenhouses in Korea. Trans ASABE 51(4):1417-1432

Huijbregts MAJ, Thissen U, Guinée JB, Jager T, Kalf D, van de Meent D, Ragas AMJ, Wegener Sleeswijk A, Reijnders L (2000) Priority assessment of toxic substances in life cycle assessment. Part I: calculation of toxicity potentials for 181 substances with the nested multi-media fate, exposure and effects model USESLCA. Chemosphere 41(4):541-573

IPCC (1997) IPCC (Revised 1996) Guidelines for National Greenhouse Gas Inventories. Intergovernmental Panel on Climate Change, Paris

IPCC (2001) Climate Change 2001: The Scientific Basis. Contribution of Working Group I to the Third Assessment Report of the Intergovernmental Panel on Climate Change, $882 \mathrm{pp}$

ISO IOFS (2006) ISO 14040-Environmental management-life cycle assessment - principles and framework, Geneva. 
Jeannequin B, Dosba F, Amiot-Carlin MJ (2005) Un point sur la filière fruits et légumes - caractéristiques et principaux enjeux. INRA éditions, Paris

Jolliet O (1993) Bilan écologique de la production de tomates en serre. Revue suisse Vitic. Arboric Hortic 25(4):261-267

Jolliet O., Saadé M., Crettaz P. (2005) Analyse du cycle de vie: comprendre et réaliser un écobilan. Presses Polytechniques et Universitaires Romandes, Collection gérer l'environnement

Lecompte F, Bressoud F, Parès L, De Bruyne F (2008) Root and nitrate distribution as related to the critical plant-N status of a fertigated tomato crop. Journal of Horticultural Science and Biotechnology 83:223-231

Nicot P, Baille A (1996) Integrated control of Botrytis cinerea on greenhouse tomatoes. In: Morris C (ed) Aerial plant surface microbiology. Plenum Press, New York, pp 169-189

Nienhuis JK (1996) Utility of the environmental life cycle assessment method in horticulture. Acta Hort (ISHS) 429:531-538

NYSERDA (New York State Energy Research and Development Authority) (2009) Energy investments and $\mathrm{CO}_{2}$ emissions for fresh produce imported into New York State compare to the same crops grown locally. State of New York, Albany, NY. http://www.nyserda.org/publications/locally $\% 20$ grown $\%$ $20 \mathrm{imported} \% 20$ produce.pdf. Accessed July 2009

Pluimers JC, Kroeze C, Bakker EJ, Challa AH, Nordijk L (2000) Quantifying the environmental impact of production in agriculture and horticulture in The Netherlands: which emissions do we need to consider? Agric Syst 66:167-189

Reinhardt W., Albright L. and de Villiers D.S. (2008) Energy investments and $\mathrm{CO}_{2}$ emissions for fresh produce imported into
New York State compared to the same crops grown locally. New York State Energy Research and Development Authority. Report 08-10, USA

Sedilot C, Degas L, le Quillec S, Brajeul E, Grasselly D (2002) Management of greenhouse effluents: a status report for France. (La gestion des effluents des serres: l'etat des lieux en France.). Infos-Ctifl 181:50-52

SIMAPRO. (2007) Ecoinvent life Cycle Inventory Database, Printerweg 18-3821 AD Amersfoort, the Netherlands

Stanhill G (1980) The energy cost of protected cropping: a comparison of six systems of tomato production. J Agric Eng Res 25:145-154

Tong G, Christopher DM, Li B (2009) Numerical modelling of temperature variations in a Chinese solar greenhouse. Comput electron agric 68(1):129-139

van Woerden (2001) The application of Life Cycle Analysis in glasshouse horticulture. International Conference LCA in Foods. Gothenburg, no 143, pp 136-140

Vésine E, Grisey A, Pommier F, Chantry A, Plasentin J, Chassériaux $\mathrm{G}, 2007$. Utilisation rationnelle d'énergie dans les serres: situation technico-économique en 2005 et leviers d'action actuels et futurs. Etude réalisée pour le compte de l'ADEME. Available at: http://www2.ademe.fr/servlet/getDoc?cid=96\&m=3\&id= $44445 \& p 1=02 \& p 2=07 \& r e f=17597$

Williams AG, Audsley E, Sandars DL (2006) Determining the environmental costs and resources use in the production of agricultural and horticultural commodities. Main Report. Defra Research Project ISO205. Cranfield University and Defra, Bedford. Available at: http://www.defra.gov.uk 